\title{
Doświadczenia i perspektywy procesu Power to Gas
}

Przedmiotem artykułu jest omówienie kluczowych zagadnień istotnych z punktu widzenia wdrażania technologii Power to Gas. Dokonano przeglądu rozwiązań technicznych w procesie Power to Gas i omówiono kierunki zagospodarowania jego produktów, a także przedstawiono aktualny stan w zakresie wdrożenia tej technologii oraz perspektywy jej rozwoju. Słowa kluczowe: Power to Gas, elektroliza, metanizacja, niestabilne źródła energii odnawialnej.

\section{Experiences and perspectives of Power to Gas technology}

The subject of the article is to discuss key issues related to the Power to Gas technology. The article presents technical solutions in the PtG process chain. The possibilities of PtG products use are discussed and the opportunities and perspectives of this technology's development are presented.

Key words: Power to Gas, electrolysis, methanization, unstable renewables.

\section{Wprowadzenie}

Efekt cieplarniany wynikający z energetycznego wykorzystania paliw kopalnych, jak również postępujący niedobór ich zasobów to przyczyny rozwoju obszaru odnawialnych źródeł energii. Ze względów ekonomicznych oraz technologicznych największy udział wśród nich mają urządzenia fotowoltaiczne i turbiny wiatrowe. W roku 2015 moc nowo zainstalowanych turbin wiatrowych na świecie wyniosła $63 \mathrm{GW}$ [4], a urządzeń fotowoltaicznych $50 \mathrm{GW}$ [15]. W roku 2015 ogólna moc turbin wiatrowych osiągnęła wartość $433 \mathrm{GW}$, a urządzeń fotowoltaicznych $277 \mathrm{GW}$, przy ogólnej mocy zainstalowanej odnawialnych źródeł energii (z wyłączeniem elektrowni wodnych) określanej jako $785 \mathrm{GW}$. Oczekuje się dalszego wzrostu podanych wartości na poziomie kilkunastu procent rocznie. Mimo zdolności wytwarzania energii elektrycznej bez zużywania zasobów kopalnych, nieodłącznym problemem tych technologii jest ich zależność od warunków pogodowych, która prowadzi do wahań produkcji energii.

W pewnym stopniu nierównomierność pracy odnawialnych źródeł energii o niskiej mocy może być zrównoważona przez wytwarzanie energii $w$ konwencjonalnych instalacjach, ale zapewnienie wyższego udziału OZE w całkowitym zużyciu energii wymaga poprawy technologii magazynowania energii. Podczas gdy baterie lub kondensatory nadają się do krótkotrwałego przechowywania energii elektrycznej, magazynowanie długoterminowe może być realizowane za pomocą wodoru jako nośnika energii.

Technologia umożliwiająca przetworzenie energii elektrycznej w okresach jej szczytowej produkcji w inne formy energii, w celu długoterminowego magazynowania, jest określana jako Power to Gas (PtG, $\mathrm{P} 2 \mathrm{G})$.

\section{Przegląd rozwiązań technologicznych w procesie Power to Gas}

Podstawowym etapem technologii PtG jest konwersja energii elektrycznej na energię chemiczną, która zachodzi w procesie elektrolizy wody. W tym etapie wykorzystuje się wygenerowane nadwyżki energii elektrycznej pochodzące z odnawialnych źródeł energii pracujących z nierówno- mierną wydajnością. Produktami elektrolizy są wodór i tlen w postaci gazowej.

Elektrolizery stosowane w procesie PtG powinny spełniać specjalne wymagania, takie jak: wysoka sprawność, możliwość eksploatacji w trybie dynamicznym ze względu 
na zmienny pobór mocy z odnawialnych źródeł energii, niska wartość dopuszczalnego minimalnego obciążenia, możliwość wytwarzania wodoru pod zwiększonym ciśnieniem w celu zmniejszenia zapotrzebowania na energię i zminimalizowania kosztów inwestycyjnych układu sprężania, długa żywotność i niskie koszty inwestycyjne.

Do realizacji procesu elektrolizy w technologii Power to Gas wykorzystywane są trzy rozwiązania: elektroliza alkaliczna (AEL), elektroliza membranowa (PEM) i elektroliza stałotlenkowa (SOEC).

Spośród podanych trzech technologii elektrolizy najbardziej rozwiniętym i znanym rozwiązaniem jest elektroliza alkaliczna. Rozwiązanie komercyjne dostępne jest na rynku od dziesięcioleci. W elektrolizerach alkalicznych metalowe elektrody, wykonane z perforowanej stali i pokryte katalizatorem na bazie niklu, kobaltu lub żelaza, zawieszone są w wodnym roztworze elektrolitu o wysokiej przewodności, $\mathrm{NaOH}$ lub $\mathrm{KOH}$. Elektrody są oddzielone membraną o wysokiej izolacyjności, umożliwiającą selektywne odprowadzanie wytwarzanych gazów w celu zapobieżenia powstawaniu mieszaniny wybuchowej.

Elektroliza alkaliczna może być prowadzona pod ciśnieniem zarówno atmosferycznym, jak i podwyższonym (do 30 bar). T. Smolinka i współpracownicy [17] ustalili, że pod zwiększonym ciśnieniem elektrolizery alkaliczne mają niższą wydajność i wytwarzają produkt o mniejszej czystości niż w procesie pod ciśnieniem atmosferycznym. Główną zaletą procesu ciśnieniowego, w porównaniu z prowadzonym pod ciśnieniem atmosferycznym, jest wymagany mniejszy dodatkowy pobór energii przy wprowadzaniu sprężonego wodoru do sieci. Zakres temperatur pracy przemysłowych elektrolizerów alkalicznych wynosi $40 \div 100^{\circ} \mathrm{C}$; zazwyczaj $70 \div 80^{\circ} \mathrm{C}$ dla procesu przebiegającego pod ciśnieniem atmosferycznym i $90 \div 100^{\circ} \mathrm{C}$ dla elektrolizerów ciśnieniowych. Sprawność osiąga poziom pomiędzy $60 \div 70 \%$ [12].

W porównaniu z elektrolizą alkaliczną, elektroliza z membraną polimerową (PEM) jest stosunkowo nową technologią. Elektrolitem w tego typu elektrolizerach jest cienka membrana selektywnie przewodząca protony do katody, spełniająca zarazem rolę membrany separacyjnej. Membrana jest bezpośrednio połączona z elektrodami pokrytymi katalizatorem. Najbardziej efektywny jest katalizator platynowy, jednak ze względu na jego wysokie koszty stosuje się też elektrody wykonane z niklu lub niklowanego żelaza. Temperatura pracy, ze względu na trwałość materiału polimerowego, jest ograniczona do około $80^{\circ} \mathrm{C}$ [17]. Wodór może być wytwarzany pod ciśnieniem do 100 bar. Możliwe jest osiągnięcie sprawności na poziomie od $65 \%$ do $83 \%$ [12], która zależy od wielu parametrów, takich jak: ciśnienie robocze, temperatura i zakres mocy. Wpływa na nią również wiek elektrolizera powodujący degradację elementów.
Trzecia z technologii - wysokotemperaturowa elektroliza parowa jest na etapie badań podstawowych. Jako elektrolit w elektrolizerach tego typu służy membrana ceramiczna, zazwyczaj wykonana $\mathrm{z}$ tlenku cyrkonu z domieszką tlenku itru. Temperatura elektrolizy wynosi $850 \div 1200^{\circ} \mathrm{C}$. Koszt elektrolizerów wysokotemperaturowych jest obecnie bardzo wysoki z uwagi na stosowane do ich budowy materiały. Proces elektrolizy wymaga dużych nakładów energetycznych. Największymi wadami elektrolizerów stałotlenkowych (SOEC) są szybka degradacja materiału i jego ograniczona trwałość ze względu na wysokie temperatury pracy [17]. Ponadto strumień produktu $\mathrm{z}$ elektrolizera jest mieszaniną wodoru oraz pary wodnej i wymaga dodatkowych operacji przetwarzania, co zwiększa koszt inwestycji. Z powodu wrażliwości materiałów ceramicznych korzystna jest praca ciągła. Warunek ten jest niemożliwy do spełnienia w przypadku instalacji PtG ze względu na wahania zasilania, częste wyłączenia i ponowne uruchamianie $[6,17]$.

Najczęściej w instalacjach Power to Gas jest stosowana elektroliza alkaliczna. Elektrolizery alkaliczne wykorzystano bądź planuje się wykorzystać w około 70\% instalacji PtG. W pozostałych przypadkach zastosowano technologię PEM. W dwóch przypadkach wykorzystane zostały oba typy elektrolizerów. Elektrolizery PEM są stosowane w niższym zakresie mocy w porównaniu z jednostkami alkalicznymi i nie są jeszcze przystosowane do dużych obiektów, choć firmy Siemens i Proton Onsite opracowały urządzenia o mocy rzędu MW.

Technologia SOEC jest na etapie doświadczalnym, pierwsze próby jej zastosowania dotyczą projektów realizowanych we Francji i w Niemczech.

Koszty inwestycyjne elektrolizerów alkalicznych są znacznie niższe niż w przypadku elektrolizerów z membraną polimerową i stałotlenkowych. Szacowane są na około $1000 € / \mathrm{kW}$, dwukrotnie mniej niż dla elektrolizerów PEM, choć według prognoz firmy Siemens [14] koszty inwestycyjne elektrolizerów typu PEM spadną do wartości mniejszej niż $1000 € / \mathrm{kW}$ już w 2018 roku. W przypadku elektrolizerów typu SOEC dostępne informacje o kosztach dotyczą tylko instalacji doświadczalnych.

Wśród problemów, które wystąpiły w czasie eksploatacji elektrolizerów alkalicznych, zauważono m.in. degradację elektrod i membrany separacyjnej, zmniejszenie wydajności po 5 latach pracy, zagrożenia spowodowane użytkowaniem alkalicznego roztworu elektrolitu, problemy z zasilaniem ze źródeł energii pracujących w sposób przerywany i zmienny, takie jak opóźniona reakcja oraz trudności w uruchomieniu układu po wyłączeniu, brak zdolności pracy przy obciążeniu poniżej 20\% wartości nominalnej, zmierzoną sprawność o 20\% niższą niż deklarowana przez producenta [12]. Z uwagi 
na wysoką korozyjność stosowanych elektrolitów, co 7 $\div 12$ lat konieczny jest ogólny przegląd instalacji [17]. Mimo to oczekiwany czas życia, wynoszący dla elektrolizera alkalicznego około 30 lat [8], w porównaniu z innymi rozważanymi typami elektrolizerów jest okresem długim.

W porównaniu z elektrolizerami alkalicznymi elektrolizery typu PEM wykazują lepszą płynność uruchomienia oraz szerszy zakres operacyjny (od 5 do 100\% mocy znamionowej). Nie są wymagane elementy wyposażenia pomocniczego, ponieważ w elektrolizerze PEM nie stosuje się obiegu ciekłego elektrolitu. Ponadto czystość wytwarzanego $\mathrm{H}_{2}$ jest bardzo wysoka (klasa 5) [11]. Zaletą elektrolizerów PEM jest również bezpieczny elektrolit, który w razie wycieku nie stwarza zagrożenia dla środowiska naturalnego. Jednak elektrolizery PEM mają krótszy czas eksploatacji, ich producenci mogli udzielić tylko $6 \div 12$ miesięcy gwarancji, przy spodziewanym czasie funkcjonowania instalacji wynoszącym 5 lat. Inne problemy techniczne związane z eksploatacją elektrolizerów typu PEM dotyczą zamarzania membrany w zimie, bardzo szybkiej degradacji stosu i niższej wydajności.

Ze względu na wahania zasilania i w konsekwencji przerywaną pracę elektrolizera, trzeba przewidzieć konieczność tymczasowego magazynowania wodoru. Możliwe jest zastosowanie do tego celu kilku metod: zbiorników na gaz sprężony, zbiorników na kriogenicznie sprężony ciekły wodór, magazynowania w postaci wodorków metali, przechowywania w podziemnych magazynach (np. kawernach solnych). Niestabilne ciśnienie, stałe wycieki gazu i koszty zaizolowania powodują, że magazynowanie wodoru w postaci ciekłej w warunkach kriogenicznych jest ze względów ekonomicznych trudne do zaakceptowania dla procesu PtG. Magazynowanie wodoru w podziemnych kawernach, chociaż jest opcją najtańszą ze wszystkich metod tutaj wymienionych, jest bardziej właściwe dla dużej pojemności i długoterminowego przechowywania wodoru. Nie stanowi więc dobrego rozwiązania dla instalacji PtG realizowanych w małej skali, które wymagają przechowywania na miejscu i w krótkim okresie. Najczęściej stosowaną metodą $\mathrm{w}$ instalacjach PtG jest przechowywanie wodoru w zbiornikach wysokociśnieniowych (350 do 700 bar), wykorzystane w niemal 90\% projektów, zarówno zaplanowanych, jak i zrealizowanych. Wynika to z różnych zalet tej technologii, takich jak dostępność na rynku, niskie koszty i wysoka pojemność. Dużo bardziej kosztowną alternatywą dla sprężania wodoru jest magazynowanie w zbiornikach wodorków metali zainstalowanych w ok. $10 \%$ instalacji. Rozwiązanie to jest jeszcze w fazie rozwojowej i stwarza problemy związane przede wszystkim z gospodarką cieplną i bezpieczeństwem eksploatacji.

Drugim etapem realizowanym w części instalacji Power to Gas jest metanizacja. W procesie metanizacji drugim, obok wodoru, reagentem jest dwutlenek lub tlenek węgla. Powinien on być dostarczany ze źródła wymagającego niewielkich nakładów ekonomicznych i energetycznych, umożliwiającego łatwe przystosowanie szybkości wytwarzania w celu pokrycia zmieniającego się zapotrzebowania. Dwutlenek węgla stosowany w procesie metanizacji może być uzyskiwany ze źródeł biologicznych, np. biogazu pochodzenia rolniczego, gazu z fermentacji osadów ściekowych lub ze zgazowania biomasy. Źródłem węgla może być też $\mathrm{CO}_{2}$ wychwytywany w procesie CCS (Carbon Capture Storage - wychwytywanie i magazynowanie węgla) w celu zmniejszenia efektu cieplarnianego, pochodzący z dużych instalacji, takich jak elektrownie i rafinerie, a także z przemysłu żelaza, stali i cementu. Proces ten jest bardzo kosztowny w odniesieniu do uzyskanej ilości $\mathrm{CO}_{2}$, którego wykorzystanie w procesie metanizacji wymagałoby głębokiego uzdatniania $\mathrm{w}$ celu usunięcia zanieczyszczeń. Ponadto dla zagospodarowania emisji $\mathrm{CO}_{2} \mathrm{z}$ elektrowni i procesów przemysłowych konieczne byłoby zastosowanie ogromnych elektrolizerów, a technologia Power to Gas wymaga znacznie mniejszych źródeł węgla.

Najczęściej stosowanym źródłem węgla do metanizacji w PtG jest biomasa. Procesy wykorzystujące biomasę można podzielić na fermentację, zgazowanie i spalanie. Podczas gdy spalanie i zgazowanie są technicznie zbliżone do procesów opartych na paliwach kopalnych, wytworzenie biogazu w trakcie fermentacji biomasy daje możliwość zagospodarowania $\mathrm{CO}_{2}$ stanowiącego produkt odpadowy.

Proces metanizacji prowadzony w komorze fermentacyjnej (metanizacja in situ) eliminuje etap oczyszczania biogazu. Przy wprowadzaniu biogazu z komory fermentacyjnej do oddzielnego reaktora, po ewentualnym usunięciu zanieczyszczeń takich jak $\mathrm{H}_{2} \mathrm{~S}$, merkaptany i siloksany, nie ma potrzeby oddzielania $\mathrm{CO}_{2}$. Alternatywnie można wykorzystać $\mathrm{CO}_{2} \mathrm{z}$ instalacji wzbogacania biogazu (instalacje wytwarzania biometanu). Szczególnie w Niemczech, ale także w innych krajach europejskich, istnieje już znaczny potencjał pozyskania $\mathrm{CO}_{2}$ z instalacji biogazowych. Według Europejskiego Stowarzyszenia Biogazu (EBA European Biogas Association) [3], w Europie w 2014 roku produkcja biometanu osiągnęła wartość ponad $1,5 \mathrm{mld} \mathrm{m}^{3}$. W przyszłości ważną rolę może odgrywać proces zgazowania biomasy - Biomass to Gas (BtG) w połączeniu z PtG. Ponieważ w Europie istnieje tylko kilka zakładów zgazowania biomasy, proces ten nie jest jeszcze dostępnym źródłem węgla w większości krajów.

Metanizacja $\mathrm{w}$ instalacji PtG może być prowadzona w procesie biologicznym bądź katalitycznym. Proces metanizacji katalitycznej polega na uwodornieniu dwutlenku węgla do metanu w temperaturze od 250 do $400^{\circ} \mathrm{C}$ pod ciśnieniem do 80 bar z wykorzystaniem katalizatorów na bazie niklu i rutenu. Zastosowanie Ni jest optymalne ze względu na jego 
aktywność, selektywność i koszt, ale wymaga zasilania bardzo czystym gazem. Ponieważ reakcja metanizacji jest egzotermiczna, najwyższą konwersję osiąga się w niskich temperaturach, co jednocześnie prowadzi do zmniejszenia jej szybkości.

$\mathrm{Z}$ tego powodu znaczącym problemem w reaktorze metanizacji jest zapewnienie odpowiedniej kontroli temperatury w celu uniknięcia ograniczeń termodynamicznych i spiekania katalizatora. W celu spełnienia tego warunku opracowano kilka koncepcji reaktorów, takich jak: reaktory ze złożem nieruchomym, złożem fluidalnym, trójfazowe oraz reaktory strukturalne. Zastosowanie reaktorów ze złożem fluidalnym, a także reaktorów ze złożem nieruchomym to rozwiązania przetestowane komercyjnie, inne koncepcje reaktorów są w fazie rozwoju.

Obecnie najbardziej rozpowszechnioną metodą jest metanizacja w warunkach adiabatycznych w reaktorze ze złożem nieruchomym. Dla zwiększenia efektywności usuwania ciepła reakcji zwykle stosuje się serię reaktorów połączonych szeregowo, z chłodzeniem międzystopniowym bądź z recyrkulacją gazu. W reaktorach ze złożem fluidalnym mieszanie fluidyzowanych cząstek prowadzi niemal do izotermicznych warunków w reaktorze, ułatwiając kontrolę procesu. Możliwość bardziej efektywnego odprowadzania ciepła jest główną zaletą tej koncepcji, co pozwala na zastosowanie pojedynczego reaktora o dość prostej budowie. Niemniej jednak, ze względu na wysokie obciążenia mechaniczne wynikające z fluidyzacji, zachodzi ścieranie się katalizatora, co może prowadzić do jego dezaktywacji. Kolejnym problemem może być niepełna konwersja $\mathrm{CO}_{2} \mathrm{i}$ ograniczona prędkość gazu w reaktorze. W trójfazowym reaktorze metanizacji katalizator stały w postaci proszku jest zawieszony w odpornej na temperaturę cieczy obojętnej, np. olejowym nośniku ciepła, takim jak dibenzyltoluen. Obecność fazy ciekłej o wysokiej pojemności cieplnej pozwala na skuteczną i dokładną regulację temperatury, umożliwia odprowadzenie ciepła reakcji, zapewniając pracę reaktora praktycznie w warunkach izotermicznych, co jest szczególnie korzystne dla przebiegu metanizacji w okresach wahań lub przerw w zasilaniu. Ponadto możliwa jest wymiana katalizatora w czasie pracy reaktora. Główna wada metanizacji trójfazowej to wysokie opory wnikania masy po stronie cieczy, zmniejszające szybkość reakcji.

Drugim rozwiązaniem procesu metanizacji stosowanym w instalacjach PtG jest metanizacja biologiczna, w której funkcję biokatalizatorów pełnią mikroorganizmy metanogenne. Wytwarzanie metanu bezpośrednio z $\mathrm{CO}_{2} \mathrm{i}_{2}$ zachodzi przy udziale mikroorganizmów typu Archea. Metanizacja biologiczna przebiega $\mathrm{w}$ warunkach beztlenowych $\mathrm{w}$ temperaturze pomiędzy $20 \mathrm{i} 70^{\circ} \mathrm{C}$ (mezofilna bądź termofilna), przeważnie pod ciśnieniem otoczenia. Ze względu na słabą rozpuszczalność wodoru w cieczy fermentacyjnej (głównie stanowi ją woda), około 25 razy mniejszą niż dwutlenku węgla w zakresie temperatur metanizacji, najbardziej istotna jest intensyfikacja dostarczania wodoru do mikroorganizmów. $\mathrm{W}$ procesach metanizacji biologicznej zazwyczaj stosuje się reaktory zbiornikowe z mieszaniem ciągłym. Zwiększenie szybkości mieszania poprawia wnikanie wodoru do cieczy, jednak konsekwencją wzrostu częstotliwości mieszania jest większe zużycie energii.

Są dwie koncepcje technologiczne procesu metanizacji biologicznej: metanizacja in situ w komorze fermentacyjnej i metanizacja w oddzielnym reaktorze.

W procesie metanizacji in situ komory fermentacyjne biogazowni stanowią część składową procesu PtG. Wodór jest wprowadzany bezpośrednio do komory fermentacyjnej. Część lub całość $\mathrm{CO}_{2}$ wytwarzanego w procesie rozkładu octanów, in situ przekształca się w $\mathrm{CH}_{4}$, w rezultacie tworząc biogaz o wyższej zawartości metanu i wartości opałowej. Szybkość powstawania metanu w metanizacji biologicznej jest ograniczona szybkością wytwarzania $\mathrm{CO}_{2}$ w biogazowni, ponadto warunki procesu nie zawsze są dostosowane do warunków optymalnych dla metanogenów wodorotroficznych (podwyższona temperatura i ciśnienie). Nie jest jednak konieczny dodatkowy reaktor, co skutkuje niższymi kosztami inwestycyjnymi. Uzyskanie całkowitej konwersji $\mathrm{CO}_{2}$ zawartego w biogazie wytworzonym w komorze fermentacyjnej jest bardzo trudne. Dla biogazowni wykorzystujących rośliny energetyczne jako surowiec zawartość metanu może być zwiększona z 52 do $75 \%$. W instalacjach biogazu z odpadów można uzyskać zawartość metanu większą niż 97\% (obie wartości zostały podane w wynikach badań firmy MicrobEnergy GmbH, Niemcy) [7].

Koncepcja metanizacji w zewnętrznym reaktorze nie ogranicza się do biogazu jako źródła węgla. Kolejną zaletą jest możliwość dostosowania warunków procesowych i konstrukcji reaktora do wymagań metanizacji biologicznej. Obecnie opracowywanych jest kilka koncepcji reaktora metanizacji biologicznej w celu zwiększenia szybkości tworzenia metanu przez zmniejszenie ograniczeń wymiany masy gaz-ciecz. Oprócz reaktorów $\mathrm{z}$ ciągłym mieszaniem badane są reaktory ze złożem stałym, trójfazowe i membranowe.

W badaniach mających na celu porównanie metanizacji biologicznej i katalitycznej stwierdzono, że w stosunku do metanizacji biologicznej metanizacja $\mathrm{CO}_{2} \mathrm{w}$ reaktorze katalitycznym z nieruchomym złożem oraz metanizacja w reaktorze trójfazowym zachodzą w znacznie szybszym tempie. Metanizacja biologiczna dla uzyskania porównywalnego stopnia konwersji doprowadzanego gazu wymaga reaktora większego kilka rzędów wielkości w porównaniu z adiabatycznym reaktorem ze złożem nieruchomym. Znaczące różnice między wartościami wymaganej szybkości objętościowej gazu 
dla różnych sposobów metanizacji wynikają przede wszystkim z trzech aspektów: wyższej temperatury procesu katalitycznego, wpływającej na większą szybkość reakcji, oporu przenoszenia masy gaz-ciecz w obecności fazy ciekłej (reaktory metanizacji biologicznej i reaktory trójfazowe) i mieszania wstecznego w reaktorze z mieszaniem.

Porównując procesy metanizacji przebiegające jako część technologii PtG w warunkach dynamicznych, należy uwzględnić zarówno dopuszczalne wartości obciążenia minimalnego, jak i wpływ szybkości zmian obciążenia na przebieg procesu, ponieważ możliwość elastycznej pracy reaktora metanizacji znacznie zmniejsza koszty magazynowania wodoru. $\mathrm{Z}$ dostępnych w literaturze badań $[7,9]$ wynika, że wszystkie procesy metanizacji mogą być realizowane w warunkach dynamicznych, ale najbardziej wrażliwe na tego typu pracę lub zatrzymanie są reaktory metanizacji ze złożem nieruchomym. Zmiany obciążenia wywołują zmiany temperatury w złożu katalizatora, powodując spowolnienie reakcji, a nawet mogą przyczynić się do uszkodzenia katalizatora metanizacji. Faza ciekła obecna w biologicznym i trójfazowym reaktorze metanizacji buforuje efekt zmian obciążenia.

Metanizacja biologiczna jest procesem elastycznym w odniesieniu do dużych zmian obciążenia, nawet doprowadzających do wyłączenia instalacji. W wynikach badań [9] podano, że natychmiastowa zmiana obciążenia od 100 do $0 \%$ może być realizowana bez negatywnego wpływu na proces metanizacji biologicznej. Wykazano również, że ponowne uruchomienie procesu po 560 godzinach postoju było możliwe bez szkodliwych skutków.

Wyłączenie reaktora metanizacji katalitycznej jest również możliwe, jednak przed wyłączeniem reaktor powinien być przedmuchany wodorem lub gazem obojętnym. Ponadto temperaturę reaktora powinno się utrzymywać powyżej $200^{\circ} \mathrm{C}$, aby zapobiec powstawaniu karbonylków niklu, a także w celu umożliwienia szybkiego ponownego uruchomienia procesu.

Metanizacja biologiczna jest zdecydowanie bardziej odporna na obecność zanieczyszczeń w gazie zasilającym niż proces katalityczny. Stwierdzono, że składniki takie jak siarka i tlen nie mają wpływu na proces metanizacji biologicznej. Ponadto oba $\mathrm{z}$ tych komponentów mogą być częściowo usunięte w trakcie jego realizacji. Stopień usunięcia pozostałych zanieczyszczeń ze strumienia wylotowego z reaktora metanizacji biologicznej i dobór metod uzdatniania zależą od przewidywanego sposobu wykorzystania produktu.

W przypadku metanizacji katalitycznej związki siarki i azotu są trucizną dla katalizatorów niklowych stosowanych w procesie. Dlatego gaz zasilający musi zostać dokładnie oczyszczony przed wejściem do reaktora metanizacji katalitycznej (dopuszczalna zawartość związków siarki - około 1 ppm).

Podsumowując rozważania na temat metanizacji w procesie PtG, można stwierdzić, że zarówno proces metanizacji biologicznej, jak i katalitycznej mają potencjał do włączenia do technologii PtG. Metanizacja biologiczna jest idealna ze względu na prosty przebieg procesu i tolerancję zanieczyszczeń gazowych. Jej wadami są: wolniejsze czasy reakcji, wyższe zapotrzebowanie na energię elektryczną, brak możliwości wykorzystania strumienia ciepła odpadowego prowadzący do efektywności procesu niższej niż dla metanizacji katalitycznej oraz wymagana duża objętość właściwa reaktora, co powoduje, że metanizacja biologiczna jest atrakcyjnym rozwiązaniem tylko dla małych instalacji i w przypadku zanieczyszczonych gazów zasilających. Obecnie metanizacja biologiczna jest przedmiotem badań w skali laboratoryjnej lub pilotowej (np. PtG-Foulum-Projekt, przepływ gazu zasilającego $50 \mathrm{~m}^{3} / \mathrm{h} \mathrm{H}_{2}$ [7]). Wyniki tych badań pozwolą na uzyskanie doświadczenia niezbędnego dla dalszego rozwoju technologii.

Rozwiązania techniczne metanizacji katalitycznej prowadzonej w warunkach izotermicznych (np. reaktory trójfazowe, reaktory ze złożem fluidalnym) wydają się być najlepsze dla instalacji średniej wielkości. Konfiguracja procesu jest stosunkowo prosta i możliwe jest wykorzystanie ciepła odpadowego. Metanizacja w reaktorze ze złożem stałym nadaje się do instalacji o dużej skali (>100 MW) ze względu na dostępne rozwiązania komercyjne.

\section{Kierunki zagospodarowania produktów gazowych procesu Power to Gas}

Produktami pierwszego etapu procesu Power to Gas, czyli elektrolizy wody przy wykorzystaniu nadwyżek energii z odnawialnych źródeł energii, są wodór i tlen. Jak dotąd w żadnej instalacji PtG nie zostało wdrożone wykorzystanie tlenu, choć rozważaną opcją jest zastosowanie go do wstępnego odsiarczania biogazu.

W przedstawionych $[4,18]$ przypadkach około 60 . instalacji zrealizowanych i planowanych, w przeważającej liczbie instalacji Power to Gas (ponad 70\% omawianych przypad- ków), produktem końcowym jest wodór, w około $25 \%$ projektów metan, a w czterech projektach metanol i inne związki. Wynika to $\mathrm{z}$ faktu, że wodór jest dobrym nośnikiem energii i unika się jego dalszego przetwarzania z powodu nieuniknionych strat efektywności procesu w przypadkach, gdy możliwe jest energetyczne wykorzystanie samego wodoru.

Wodór otrzymany w procesie elektrolizy w instalacjach Power to Gas charakteryzuje się wysoką czystością i może być wykorzystany w różny sposób, np. do produkcji energii 
elektrycznej w ogniwach paliwowych, silnikach z wewnętrznym spalaniem i instalacjach kogeneracyjnych, jako paliwo dla pojazdów napędzanych wodorem, nośnik energii w systemie gazowniczym, substrat do syntezy metanu (lub innego paliwa węglowodorowego).

Najczęściej wykorzystuje się wodór z elektrolizy wody do produkcji energii elektrycznej (niemal w połowie projektów, w których realizowany jest tylko etap elektrolizy i produktem jest wodór). W ponad $80 \%$ przypadków elektryczność jest wytwarzana z zastosowaniem ogniw paliwowych, w pozostałych wykorzystano silnik z wewnętrznym spalaniem lub instalację kogeneracyjną. W części instalacji ciepło ogniw paliwowych używane jest do celów grzewczych. Ze względu na wysoką czystość wodoru elektrolitycznego jest on szczególnie predestynowany do stosowania w ogniwach paliwowych, spełniając bardzo restrykcyjne wymagania jakościowe [1]. Od 2000 roku instalowane są wyłącznie ogniwa paliwowe typu PEM. Ogniwa te w czasie ruchu są łatwe do utrzymania i osiągają dużą sprawność nawet przy wahaniach zasilania. Mimo to mogą sprawiać różne problemy, takie jak wewnętrzne wycieki, krótki czas pracy (poniżej 100 godzin) ze względu na szybką degradację stosu, negatywny wpływ zmian obciążenia na czas życia stosu i uszkodzenia w czasie dłuższych postojów w niskich temperaturach.

Wprowadzenie produktu gazowego procesu Power to Gas do sieci gazowej występuje w jednej trzeciej projektów. Większość z nich polega na wtłoczeniu wodoru do sieci gazu ziemnego. O ile wprowadzanie metanu z instalacji PtG do sieci gazowej nie stanowi problemu, udział wodoru w sieci gazu ziemnego jest ograniczony. Wytyczne dopuszczalnej jego zawartości w gazie sieciowym są odmienne dla różnych państw, np. w Holandii dopuszczalny udział wodoru w gazie sieciowym wynosi 2\% [13]. Na taką samą wartość zezwalają obecne przepisy w Niemczech w gazie do zasilania pojazdów samochodowych, ale zakres tolerancji w odniesieniu do sieci gazowych i nowych palników urządzeń gazowych może być wyższy [2]. Wartość podana w standardzie technicznym DVGW G262 wynosi 5\%. W załączniku A do normy EN 16726:2015 Infrastruktura Gazowa - Jakość Gazu - Grupa H stwierdza się, że w niektórych częściach systemu gazowniczego możliwe jest wprowadzenie do $10 \%$ wodoru, jakkolwiek przy stosowaniu zbiorników stalowych w pojazdach zawartość wodoru w gazie zasilającym nie powinna przekraczać $2 \%$. Dla zastosowań w turbinach gazowych obecnie zainstalowanych przewiduje się nieprzekraczanie 1\% wodoru w gazie ziemnym, przy niewielkich modyfikacjach może być dopuszczalne zwiększenie udziału wodoru do 5\%, a w niektórych nowych typach turbin do $15 \%$. Dla silników gazowych obecnie zaleca się stosowanie gazu z udziałem wodoru nieprzekraczającym $2 \%$, przy czym w specjalnie dedykowanych silnikach gazowych paliwo może zawierać do 10\% wodoru. Stwierdzono także, że większość chromatografów gazowych stosowanych w gazownictwie nie jest przystosowana do analizy wodoru. $\mathrm{Na}$ podstawie zleconych przez Niemieckie Stowarzyszenie Naukowo-Techniczne Branży Gazowniczej i Wodociągowej (DVGW) badań, przeprowadzonych w przemyśle i w ośrodkach naukowych, których wyniki zawarto w raporcie [14], zidentyfikowano dopuszczalne zawartości wodoru w gazie dla pięciu obszarów łańcucha dostaw gazu, za które uznano transport, magazynowanie, pomiar i regulację oraz dystrybucję gazu i jego użytkowanie. Dla każdego z procesów dopuszczalna zawartość wodoru została określona za pomoca trzech progów, w których mieszanie wodoru jest nieszkodliwe albo wymagana jest adaptacja technologiczna bądź regulacja administracyjna, albo zalecane jest prowadzenie dalszych prac badawczo-rozwojowych. Dla gazociągów, gazomierzy, zbiorników i większości elementów systemu dystrybucyjnego dopuszczalny udział wodoru, przy którym nie są wymagane prace adaptacyjne, kształtuje się na poziomie $20 \div 30 \%$. Największym problemem jest brak możliwości pomiaru zawartości wodoru w mieszaninie z gazem ziemnym za pomocą chromatografów procesowych zainstalowanych w Niemczech przed 2013 rokiem, dla których górna granica udziału wodoru w mieszaninie jest określona na poziomie $0,2 \%$. Według realizatorów projektów, w których wprowadzono wodór do gazu sieciowego nawet w ilości sięgającej 20\% objętości (projekty Ameland, GHRYD [18]), nie stwierdzono większych problemów z zastosowaniem mieszaniny wodoru i gazu ziemnego w urządzeniach gazowych ani z uszkodzeniem infrastruktury przesyłowej.

Trzecim z głównych zastosowań produktu gazowego $\mathrm{z}$ instalacji PtG jest paliwo transportowe. Z nielicznymi wyjątkami jako paliwo transportowe wykorzystywano wodór. Wyjątki dotyczą między innymi produkcji metanolu w instalacji w Islandii i produkcji metanu do napędu samochodów w największej obecnie działającej instalacji PtG, Audi ${ }^{\mathrm{TM}}$ w Werlte w Niemczech. Zasilanie wodorem pojazdów może odbywać się z wykorzystaniem konwencjonalnych silników z wewnętrznym spalaniem (ICES - Internal Combustion Engines) lub na drodze spalania wodoru w ogniwach paliwowych pojazdów elektrycznych (FCV - Fuel Cell Vehicles). Wyniki prób uzasadniają stwierdzenia o niezawodnym działaniu układu paliwowego i silników przy zawartości $\mathrm{H}_{2} \mathrm{w}$ CNG do 30\% [16], ale w takich przypadkach wymagane jest stosowanie kompozytowych zbiorników magazynowych. Możliwość zastosowania czystego wodoru w silnikach ICES była przedmiotem badań takich producentów samochodów jak: BMW, Ford, MAN i Mazda, ale ograniczono dalsze działania w tym zakresie, ponieważ osiągnięta 
sprawność była porównywalna z konwencjonalnymi ICES, dlatego w obszarze zastosowań czystego wodoru skoncentrowano się na badaniach FCV. Prawie wszyscy znaczący producenci ogłosili, że w latach 2015-2020 będą wprowadzać modele samochodów FCV. Główną zaletą tego rozwiązania jest wysoka wydajność ogniwa paliwowego w połączeniu z długim zakresem jazdy.

Wykorzystanie wodoru do syntezy metanu to rozwiązanie zastosowane tylko w kilkunastu przypadkach istniejących instalacji, ale uważane jest za przyszłościowe. Metan syntetyzowany z wodoru może być wprowadzany do systemu dystrybucji gazu bez żadnych ograniczeń, dlatego projekty, w których produktem końcowym jest metan, przewidują przede wszystkim jego wtłaczanie do sieci gazu ziemnego, a tylko nieliczne zakładają produkcję paliwa transportowego lub wykorzystanie metanu jako surowca dla przemysłu chemicznego. Dotyczy to jednak dużych instalacji: wspomnianej instalacji Audi ${ }^{\mathrm{TM}}$ o mocy zainstalowanej 6,3 MW i bu- dowanego zakładu o planowanej największej mocy zainstalowanej (Delfzijl, $12 \mathrm{MW}$ ).

Prawie połowa z projektów instalacji PtG jest realizowana w Niemczech. To wynik niemieckiej polityki energetycznej, zakładającej w przyszłości oparcie energetyki niemal wyłącznie na źródłach odnawialnych. Silne wsparcie polityczne jest widoczne w zestawieniach partnerów projektów; w kilku projektach jest to wsparcie federalne, landu lub samorządowe. Pozostałe kraje o największej liczbie instalacji PtG również znajdują się w Europie - są to Hiszpania, Francja, Holandia i Dania. Wynika to głównie z faktu, że istnieje silne wsparcie polityczne przekładające się na współfinansowanie projektów przez Komisję Europejską i rządy krajów europejskich oraz że w wielu krajach istnieją liczne farmy wiatrowe, a także instalacje solarne, i udział energii z odnawialnych źródeł o niestabilnej produkcji w sieci energetycznej jest na tyle znaczny, że opłaca się szukać rozwiązań równoważenia wahań dostaw tej energii.

\section{Podsumowanie}

Na podstawie analizy wdrożonych i planowanych projektów realizujących technologię PtG można stwierdzić, że ich liczba na świecie rośnie, a rozwój tej technologii staje się widoczny, zwłaszcza w Niemczech, gdzie obecnie działa ponad 20 instalacji i planowane są kolejne wdrożenia. Kluczowym problemem instalacji PtG jest to, że większość z nich pracuje krótko i tylko niewielka liczba projektów ma wieloletnie doświadczenie eksploatacyjne.

Większość instalacji PtG pracuje samodzielnie. Często są one realizowane w oddalonych lokalizacjach, w miejscach, gdzie istnieje duży potencjał wytwarzania energii odnawialnej, a ceny energii są wysokie. Zaleca się stosowanie różnych generatorów energii odnawialnej w jednostkach eksploatowanych samodzielnie, ponieważ w pewnym stopniu uzupełniają się wzajemnie, co prowadzi do bardziej zrównoważonej produkcji energii.

Perspektywy rozwoju technologii Power to Gas zależą przede wszystkim od dostępności energii ze źródeł odnawialnych o niestabilnej produkcji, czyli turbin wiatrowych i jednostek solarnych oraz od polityki kraju w dziedzinie energii ze źródeł odnawialnych. Cele polityki klimatycznej wymuszają zwiększenie udziału energii z odnawialnych źródeł w ogólnym mikście energetycznym. Niemcy, będąc liderem w technologii PtG, zakładają, że do 2030 roku, źródła odnawialne będą pokrywać $50 \%$ ich zapotrzebowania na energię, a w przyszłości udział ten jeszcze się zwiększy. W celu zapewnienia zrównoważonej pracy systemu elektroenergetycznego konieczne jest rozwiązanie problemu magazynowania energii. Niemieckie firmy energetyczne uważają techno- logię Power to Gas za modelowe rozwiązanie pozwalające szybko reagować na wahania w produkcji energii i postulują zwiększenie mocy elektrolizerów do $1 \mathrm{GW}$ do roku 2020. Zanim jednak technologia PtG zostanie wdrożona z sukcesem jako rozwiązanie komercyjne, konieczne jest pokonanie wielu barier technicznych i ekonomicznych. W procesie elektrolizy niezbędna jest poprawa wydajności procesu w stanie nieustalonym i redukcja kosztów, zwłaszcza elektrolizerów PEM. Metanizacja katalityczna wymaga opracowania koncepcji reaktora umożliwiającego efektywny przebieg procesu w warunkach dynamicznych, optymalizację odprowadzania ciepła i utrzymanie warunków izotermicznych. Niezbędne jest także zapewnienie wysokiego stopnia czystości surowców gazowych w procesie metanizacji katalitycznej. W metanizacji biologicznej konieczne jest polepszenie wymiany masy gaz-ciecz, umożliwiającej wnikanie wodoru do cieczy zawierającej mikroorganizmy. W całym procesie najwyższe koszty generuje jednak produkcja wodoru i ich zmniejszenie jest kluczowym warunkiem poprawy wskaźników ekonomicznych technologii Power to Gas.

W Polsce technologia Power to Gas jest przedmiotem umiarkowanego zainteresowania. Wynika to z niewielkiego udziału energii odnawialnej w ogólnym bilansie energii, w tym energii odnawialnej ze źródeł o niestabilnej produkcji, którymi w przypadku Polski są wyłącznie turbiny wiatrowe. Mimo bardzo dużej dynamiki w uruchamianiu nowych źródeł energii wiatrowej w latach 2014-2016, wynikającej z obaw przed zmianami legislacyjnymi, czego skutkiem jest przekroczenie 5 GW mocy zainstalowanej turbin 
wiatrowych, udział energii wiatrowej w produkcji energii elektrycznej wynosi około 5\%. W roku 2015 technologia Power to Gas stała się przedmiotem zainteresowania firm energetycznych i gazowniczych. Polska Grupa Energetyczna S.A. i Gaz-System S.A. podpisały list intencyjny w sprawie budowy testowej instalacji do magazynowania energii w postaci wodoru wytwarzanego przy użyciu nadwyżek energii elektrycznej produkowanej na farmach wiatrowych.

Prosimy cytować jako: Nafta-Gaz 2017, nr 8, s. 597-604, DOI: 10.18668/NG.2017.08.07

Artykuł nadesłano do Redakcji 9.12.2016 r. Zatwierdzono do druku 18.05.2017 r.

Artykuł powstał na podstawie pracy statutowej pt.: Przetwarzanie i uzdatnianie paliw gazowych w technologii Power to Gas - praca INiG - PIB na zlecenie MNiSW; nr zlecenia: 59/WO/16, nr archiwalny: DK-4100-59/16.

\section{Literatura}

[1] Demusiak G.: Otrzymywanie paliwa wodorowego metoda reformowania gazu ziemnego dla ogniw paliwowych matej mocy. Nafta-Gaz 2012, nr 10, s. 661-673.

[2] Dzirba D.: Gazowe sieci inteligentne - opcja dla energetyki? Nafta-Gaz 2012, nr 3, s. 184-190.

[3] EBA Biomethane \& Biogas Report 2015; http://european-biogas.eu/2015/12/16/biogasreport2015/ (dostęp: październik 2016).

[4] Gahleitner G.: Hydrogen from renewable electricity: an international review of power-to-gas pilot plants for stationary applications. Int. J. Hydrogen Energy 2013, vol. 38, s. 2039-2061.

[5] Global Wind Energy Council (GWEC) Global Wind Report Annual Market; http://www.gwec.net/wp-content/uploads/ vip/GWEC-Global-Wind-2015-Report_April-2016_22_04. pdf (dostęp: październik 2016).

[6] Gotz M., Lefebvre J., Mors F., McDaniel Koch A., Graf F., Bajohr S., Reinert R., Kolb T.: Power-to-Gas: A technological and economical review. Renewable Energy 2016, vol. 85, s. $1371-1390$.

[7] Gotz M., Mc Daniel Koch A., Graf F.: State of the art and perspectives of $\mathrm{CO}_{2}$ Methanation Process Concepts for Powerto-Gas Applications. IGU Research Conference, Kopenhaga 2014.

[8] Graf F., Götz M., Henel M., Schaaf T., Tichler R.: Abschlussbericht: Techno-ökonomische Studie von Power-to-Gas-Konzepten. Bonn 2014; http://www.dvgw-innovation.de/fileadmin/ dvgw/angebote/forschung/innovation/pdf/g3 (dostęp: sierpień 2016).

[9] Graf F., Krajete A., Schmack U.: Abschlussbericht: Technoökonomische Studie zur biologischen Methanisierung bei Power-to-Gas-Konzepten. Bonn 2014; http://www.dvgwinnovation.de/fileadmin/dvgw/angebote/forschung/innovation/ pdf/g3_01_13.pdf (dostęp: październik 2016).

[10] Grond L., Schulze P., Holstein J.: Systems analyses Power to Gas: A technology review. TKI Gas project TKIG01038, DNV GL 2014 (dostęp: wrzesień 2016).

[11] Hacker B., Gesikiewicz P., Smolinka T.: Arbeitspaket 1b: Systemoptimierung und Betriebsführung der PEM-Elektrolyse energie|wasser-praxis, 65 (2015), s. 37-40; http://www.dvgwinnovation.de/fileadmin/dvgw/angebote/forschung/innovation/ pdf (dostęp: wrzesień 2016).
[12] Hollady J.D., Hu J., King D.L., Wang Y.: An overview of hydrogen production technologies. Catal. Today 2009, vol. 139, s. 244-260.

[13] IPHE renewable hydrogen report (2011); http://www.iphe net.docs/Renevable_H2_Rpt_040411.pdf (dostęp: sierpień 2016).

[14] Müller-Syring G., Henel M., Köppel W., Mlaker H., Sterner M., Höcher T.: Entwicklung von modularen Konzepten zur Erzeugung, Speicherung und Einspeisung von Wasserstoff und Methan ins Erdgasnetz Abschlussbericht DVGW-Projekt G1-07-10 DBI Gas- und Umwelttechnik GmbH, Bonn 2013; http://www.dvgw-innovation.de/fileadmin/dvgw/angebote/ forschung/innovation/pdf/gl 07 10.pdf (dostęp: wrzesień 2016).

[15] Renewables 2015 Global Status Report, REN 21; http://www. ren21.net/wp-content/uploads/2016/06/GSR_2016_Full_Report.pdf (dostęp: wrzesień 2016).

[16] Schiebahn S., Grube T., Robinius M., Tietze V., Kumar B., Stolten D.: Power to gas: Technological overview, systems analysis and economic assessment for a case study in Germany. Int. J. Hydrogen Energy 2015, vol. 40, s. 4285-4294.

[17] Smolinka T., Günther M., Garche J.: NOW-Studie - Stand und Entwicklungspotenzial der Wasserelektrolyse zur Herstellung von Wasserstoff aus regenerativen Energien, 2011; http://www.hs-ansbach.de/uploads/tx nxlinks/NOW-StudieWasserelektrolyse-2011.pdf (dostęp: lipiec 2016).

[18] Vartiainen V.: Screening of Power to Gas Projects; http:// www.doria.fi/bitstream/handle/10024/123485/diplomityo_vartiainen_vesa.pdf?sequence (dostęp: październik 2016).

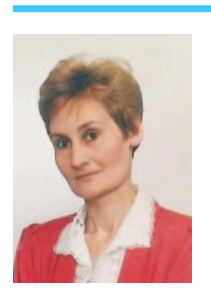

Mgr inż. Julita PISKOWSKA-WASIAK

Starszy specjalista badawczo-techniczny w Zakładzie Technologii Oczyszczania i Nawaniania Paliw. Instytut Nafty i Gazu - Państwowy Instytut Badawczy ul. Lubicz 25 A

31-503 Kraków

E-mail: piskowska@inig.pl 